\title{
Corrosion Study of Al-Fe (20 wt\%) Alloy in Seawater Alkaline Solutions
}

\author{
J.E. Flores-Chan ${ }^{1, *}$, A. Torres-Islas ${ }^{2}$, C. Patiño-Carachure ${ }^{3}$, G. Rosas ${ }^{1}$, M.A. Espinosa-Medina, ${ }^{4, *}$ \\ ${ }^{1}$ Instituto de Investigación en Metalurgia y Materiales, UMSNH, C.P. 58000, Morelia, Mich. México. \\ ${ }^{2}$ Facultad de Ciencias Químicas e Ingeniería Mecánica, Universidad Autónoma del Estado de \\ Morelos. C.P. 62209, Cuernavaca, Morelos, México. \\ ${ }^{3}$ Facultad de Ingeniería, Universidad Autónoma del Carmen, Campus III, Av. Central S/N, Esq. con \\ Fracc. Mundo Maya, C.P. 24115 MSNH, Ciudad del Carmen, Campeche, México. \\ ${ }^{4}$ Facultad de Ingeniería Mecánica, UMSNH, C.P. 58000, Morelia, Mich. México. \\ *E-mail: marespmed@gmail.com, enri_flores@ hotmail.com
}

doi: $10.20964 / 2016.09 .36$

Received: 30 May 2016 / Accepted: 8 July 2016 / Published: 7 August 2016

The assessment of corrosion susceptibility of the Al-Fe (20 wt $\%)$ alloy in seawater at different alkaline $\mathrm{pH}$ values was performed applying potentiodynamic polarization, linear polarization resistance (LPR) and electrochemical impedance spectroscopy (EIS) techniques. The electrochemical results carried out at room temperature showed lower values of the corrosion current density of about $0.008-0.0896$ $\mathrm{mA} / \mathrm{cm}^{2}$. The polarization curves showed the formation of an unstable layer which decreases with the $\mathrm{pH}$ increasing. EIS results revealed a corrosion mechanism controlled by the ion transport through the permeable film. Microstructural characterization confirmed the formation of hydroxides phases as corrosion products by increasing the $\mathrm{pH}$ and exposure time.

Keywords: Al-Fe (20 wt\%) alloy, electrochemical techniques, seawater.

\section{$\underline{\text { FULL TEXT }}$}

(C) 2016 The Authors. Published by ESG (www.electrochemsci.org). This article is an open access article distributed under the terms and conditions of the Creative Commons Attribution license (http://creativecommons.org/licenses/by/4.0/). 